\title{
Risk Perception and Adherence to Preventive Behaviors by the Public Amid COVID-19 Pandemic; A Community-Based Study Applying the Health Belief Model
}

\author{
Aziz Kamran \\ Ardebil University of Medical Sciences \\ Khatereh Isazadehfar \\ Ardebil University of Medical Sciences \\ Akbar Pirzadeh \\ Ardebil University of Medical Sciences \\ Ramin Nasimi Doost Azgomi \\ Ardebil University of Medical Sciences \\ Heshmatolah Heydari ( $\sim$ H-hidari@razi.tums.ac.ir) \\ Lorestan University of Medical Sciences
}

\section{Research article}

Keywords: Perception, COVID-19, Behavior, Adherence

Posted Date: November 19th, 2020

DOI: https://doi.org/10.21203/rs.3.rs-30183/v1

License: (c) (1) This work is licensed under a Creative Commons Attribution 4.0 International License.

Read Full License 


\section{Abstract}

Background: COVID-19, now a global pandemic, is a new, highly contagious, and preventable disease that has caused many deaths across the world. The correct understanding of the risks and following health instructions are among the most important self-care parameters. This study was aimed to assess people's perceived risks and their adherence to recommended preventive behaviors regarding the COVID19 infection.

Methods: This descriptive-analytical study was conducted on 1861 people residing in Ardabil province in 2020. The data collected electronically by instrument which consisted from four parts: demographic specifications, the Health Belief Model (HBM) constructs (perceived sensitivity, perceived severity, and perceived benefits), beliefs on the effectiveness of disease prevention strategies, and complying with health behaviors. The data was analyzed using SPSS-21 software.

Results: Significant differences were found in the mean scores of the beliefs on the effectiveness of preventive recommendations, the constructs of the health belief model, and compliance to preventive behaviors considering the participants' gender, age, marital status, and the level of education. The beliefs and intention to stay at home, collectively predicted $54.7 \%$ of the variance of preventive behaviors.

Conclusion: Although a the majority of participants had positive attitude toward the effectiveness of preventive measures and adhered to them, some people who were not adherent to healthy behaviors could be key participants to the next waves of the disease.

\section{Background}

COVID-19 is a new infectious disease caused by a novel SARS-related coronavirus(1) where it was first reported on December 31, 2019. After a rapid spread inflicting most countries across the world, the World Health Organization (WHO) declared the disease as a pandemic on March 11, 2020 (2). Common symptoms include fever, cough, and a shortness of breath (3). Although symptoms are mild in most cases, the disease may sometimes be associated with the failure of vital organs such as lungs, the heart and kidneys (4). The disease is typically transmitted through infected respiratory droplets following coughing or sneezing (3) and can be prevented by continuous hand washing, restricting social communications, and observing health guidelines (5).

Up until May 12, 2020, the number of people infected with COVID-19 had reached more than 4 million, and the death toll had hit over than 2 thousand worldwide. The first case of COVID-19 infection in Iran was observed in Qom city on Tuesday, the February 18th, 2020(6). Afterwards, the disease started to rapidly spread, and its mortality rate faced up-ward exponentially. Until May 12, 2020, the number of confirmed cases of COVID-19 patients in Iran was 107603, and the number of deaths was 6640 . The disease pandemic means that society is in great danger, and everyone must abide by the recommendations made to reduce the disease. People's adherence to recommended behaviors has been studied in limited studies, Some have shown that compliance in SARS was not favorable (7) and another 
study found that with only half of the people in COVID19 quarantine (8). Reported reasons include poor health literacy(9) perceived threat (10)anxiety, depression(11) enabling factors, perceived benefits(12) level or urbanization, its social and religious norms(13) social norms, perceived benefits of quarantine and perceived risk of the disease(14).

From the earliest days after detecting the disease in Iran, health officials banned the public from attending group meetings and encouraged them to stay at home. However, these warnings seemed ineffective, and some people continued appearance across the community. According to our knowledge, this is the first community based study with a large number of study sample which examined adherence to recommended behavior in Iran. We used the HBM to theoretically examine behavioral predictors. The HBM is one of the models to predicting people's perceptions on social risk factors and reasons for their ignorance of warnings. This model is considered as one of common theories on health-related behaviors in research fields $(15,16)$ and regards behavior as a function of one's knowledge and attitude. The model helps people to perceive health threats and direct their behaviors toward healthy actions(17). This model has six structural components including perceived sensitivity, severity, benefits, barriers, practical guidelines, and self-efficacy. As reported in recent studies, this model can be used to provide self-care recommendations $(18,19)$. According to this model, individuals are engaged in self-care behaviors when they believe that the consequences of not adhering to such behaviors are serious. In this manner, one is encouraged to comply with preventive behaviors $(20,21)$. Considering the high capacity of this model to predict people's health-related behaviors and their perceptions on health recommendations, we decided to conduct a study to assess risk perception and the rate of adherence to preventive recommendations regarding COVID-19 infection by Iranian people. For this purpose, we used the HBM to assess factors determining the rate of social adherence to preventive measures. In this way, it is possible to implement appropriate interventions to prevent the spread of the disease across the community.

\section{Methods}

This descriptive-analytical study was conducted on 1960 people in Ardabil province between April and May 2020. A total of 1861 questionnaires were analyzed after removing incomplete ones. The data was collected electronically by submitting the questionnaires in social media that were popular across the province.

The inclusion criteria were the age of 10 to 70 years, having writing and reading abilities, owning either a smartphone, a laptop, or a computer, having access to popular social media in Iran (i.e. Telegram, WhatsApp, Baleh, and Gap). Exclusion criteria were having academic education in health-related fields (medicine, nursing, pharmacology, etc.) and filling the questionnaire incompletely. At the top of the questionnaire, declarations were provided regarding the goals of the study, as well as approvals by the Research Center for Social Sciences and the Ethic Committee of Ardabil University of Medical Sciences. In the process of ethical assessment of the research projects in the ethics committee of Ardabil University of Medical Sciences, all aspects of the researches in design, including ethics in sampling, data collection, questionnaire, and informed consent are discussed. There was no need for the participants to mention 
their personal information such as names and national IDs. The data collected electronically by distributed questionnaire in social network groups. In fact, there was no control over the participants and the information was completed by the participants' self-declaration. In order to observe the ethical

principles of completing the questionnaire by people under 16 years of age, at the beginning of the questionnaire, participants were asked to read and complete the questionnaire under the supervision of their parents if they are under 20 years old.

The data was collected using a four-part questionnaire. The first part included demographic variables. The second part was related to risk perception assessed through 3 structural constructs of the health belief model; perceived sensitivity (4 items), perceived risk (4 items), and perceived benefits ( 2 items). These parameters were determined by a 5-option Likert scale with responses from "strongly agree" to "strongly disagree". The ranges of scores on the perceived sensitivity, severity, and benefits were 4-20, 420 , and $2-10$, respectively. The third part of the questionnaire was related to the beliefs on the effectiveness of health recommendations ( 9 items). Finally, the last part of the survey assessed behaviors for preventing COVID-19 infection (9 items).

The sections of "beliefs on the effectiveness of health recommendations" and "compliance with recommended behaviors" were assessed based on a Likert scale which was scored from 1 to 7 . A score of 1 designated the lowest, and a score of 7 indicated the highest belief and compliance rates. Therefore, the scores of these two sections ranged from 9 to 63. (Additional file 1)

The validity of the questionnaire was confirmed using the face and content validity (i.e. CVI and CVR indicators). The reliability of the instrument was confirmed based on the Cronbach's alpha coefficients of 0.87 and 0.85 for the belief and behavior sections, respectively.

The data was analyzed using SPSS statistical software (version 21). Numerical variables were reported as mean \pm standard error, and qualitative variables were expressed by frequencies. For comparing the mean scores of the variables, either sample student t-test (two independent groups) or one-way ANOVA (more than two independent groups) were used. Correlations between the variables were assessed by the Pearson correlation test. Multiple linear regression test was used to evaluate the predictive value of risk perception and beliefs on the variance of social health behaviors.

\section{Results}

Our results showed that 996 (53.5\%) of the participants were female. Furthermore, 1363 (73.2\%) were married, and $877(47.1 \%)$ had an undergraduate-associate degree. Also, $638(34.3 \%)$ of the participants were housewives, and 807 (43.4\%) were in the age group of 30 to 40 years.

Overall, 970 (52.1\%) of the subjects reported that they had acquired their information merely from social media. Another 722 (38.8\%) people declared that the SMS messages sent by the Ministry of Health had weak or very weak effects on their behaviors. Finally, $1434(77.1 \%)$ and $353(19 \%)$ of the participants announced that they were agree or completely agree with the slogan of "we stay at home". 
The results showed that 15.5\% (290) participant perceived COVID19 as a simple and similar to the flu and colds, and 14.5 (272) agreed that The disease is dangerous only for the elderly and diabetics and cardiovascular patients, 7.3\% (135) participants believed that I am not in danger. The mean score of perceived sensitivity, severity and benefits was $15.9 \pm 2.2,16.5 \pm 2.2$ and $8.7 \pm 1.1$ respectively. [Table 1 ]

Table 1

Descriptive statistics for the HBM constructs

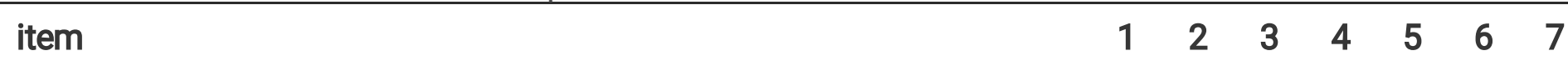

Wearing gloves out of home

Wearing mask out of home

Wearing mask out of home in contact with patients

Stay at home

Absence from family and religious ceremonies

Minimizing presence in the community, such as reducing purchases and administrative and banking visits

Frequent hand washing with disinfectant

Frequent hand washing with soap and water

Disinfection of personal items such as keychains, mobile phones and cars

The results showed that the mean score of behavior in women was significantly higher than men and the attitude towards behavior was significantly higher in men than women. $(P<0.001)$. Also, the mean score of behavior and attitude in people over 50 years and housewives was significantly higher than other age and job groups $(P<0.001)$ and farmers and ranchers reported the lowest mean score of behavior and attitude. The results showed that the mean score of behavior and the attitude towards behavior was significantly higher in married participants than others. [Table 2] 
Table 2

- Comparison of attitude and behavior between gender, age groups, jobs and marital status

\begin{tabular}{|c|c|c|c|c|c|c|c|}
\hline Constructs & Item & $\begin{array}{l}\text { Strongly } \\
\text { disagree }\end{array}$ & Disagree & $\begin{array}{l}\text { No } \\
\text { comment }\end{array}$ & Agree & $\begin{array}{l}\text { Stongly } \\
\text { agree }\end{array}$ & Mean \\
\hline \multirow[t]{4}{*}{$\begin{array}{l}\text { Perceived } \\
\text { Sensitivity }\end{array}$} & $\begin{array}{l}\text { The disease is } \\
\text { simple and } \\
\text { similar to the } \\
\text { flu and colds }\end{array}$ & $\begin{array}{l}720 \\
(38.7)\end{array}$ & $\begin{array}{l}516 \\
(27.7)\end{array}$ & 335 (18) & $213(11.4)$ & $\begin{array}{l}77 \\
(4.1)\end{array}$ & $\begin{array}{l}15.9 \\
\pm 2.2\end{array}$ \\
\hline & $\begin{array}{l}\text { The disease is } \\
\text { dangerous only } \\
\text { for the elderly } \\
\text { and diabetics } \\
\text { and } \\
\text { cardiovascular } \\
\text { patients }\end{array}$ & $\begin{array}{l}656 \\
(35.2)\end{array}$ & $\begin{array}{l}810 \\
(43.5)\end{array}$ & $\begin{array}{l}123 \\
(16.6)\end{array}$ & $181(9.7)$ & $\begin{array}{l}91 \\
(4.9)\end{array}$ & \\
\hline & $\begin{array}{l}\text { I am not in } \\
\text { danger and my } \\
\text { immune } \\
\text { system is } \\
\text { strong }\end{array}$ & $\begin{array}{l}610 \\
(32.8)\end{array}$ & $\begin{array}{l}903 \\
(48.5)\end{array}$ & $\begin{array}{l}213 \\
(11.4)\end{array}$ & $91(4.9)$ & $\begin{array}{l}44 \\
(2.4)\end{array}$ & \\
\hline & $\begin{array}{l}\text { Health advice } \\
\text { doesn't matter, } \\
\text { and it doesn't } \\
\text { affect my daily } \\
\text { behavior }\end{array}$ & $\begin{array}{l}343 \\
(18.4)\end{array}$ & $\begin{array}{l}1453 \\
(78.1)\end{array}$ & $23(1.2)$ & $23(1.2)$ & $\begin{array}{l}19 \\
(1.0)\end{array}$ & \\
\hline \multirow[t]{3}{*}{$\begin{array}{l}\text { Perceived } \\
\text { severity }\end{array}$} & $\begin{array}{l}\text { I feel it is } \\
\text { necessary to } \\
\text { reduce } \\
\text { communication } \\
\text { and personal } \\
\text { contact, and I } \\
\text { must avoid } \\
\text { infected people }\end{array}$ & $19(1)$ & $54(2.9)$ & $12(0.6)$ & $265(14.2)$ & $\begin{array}{l}1511 \\
(81.2)\end{array}$ & $\begin{array}{l}16.5 \\
\pm 2.0\end{array}$ \\
\hline & $\begin{array}{l}\text { Corona } \\
\text { Morbidity and } \\
\text { Mortality news } \\
\text { is important to } \\
\text { me and I follow } \\
\text { it }\end{array}$ & $31(1.7)$ & $24(1.3)$ & $130(7.0)$ & $810(43.5)$ & $\begin{array}{l}866 \\
(46.5)\end{array}$ & \\
\hline & $\begin{array}{l}\text { I am worried } \\
\text { about the } \\
\text { behavior of } \\
\text { others and the } \\
\text { statistics of the } \\
\text { disease in the } \\
\text { future }\end{array}$ & $22(1.2)$ & $14(0.8)$ & $70(3.8)$ & $604(32.5)$ & $\begin{array}{l}1151 \\
(61.8)\end{array}$ & \\
\hline
\end{tabular}




\begin{tabular}{|c|c|c|c|c|c|c|c|}
\hline Constructs & Item & $\begin{array}{l}\text { Strongly } \\
\text { disagree }\end{array}$ & Disagree & $\begin{array}{l}\text { No } \\
\text { comment }\end{array}$ & Agree & $\begin{array}{l}\text { Stongly } \\
\text { agree }\end{array}$ & Mean \\
\hline & $\begin{array}{l}\text { The facilities } \\
\text { and capacity of } \\
\text { the health } \\
\text { system, such } \\
\text { as doctors and } \\
\text { nurses, are } \\
\text { limited and I } \\
\text { am worried } \\
\text { about the } \\
\text { future }\end{array}$ & $\begin{array}{l}125 \\
(6.7)\end{array}$ & $24(1.3)$ & $146(7.8)$ & $627(33.7)$ & $\begin{array}{l}939 \\
(50.5)\end{array}$ & \\
\hline \multirow[t]{2}{*}{$\begin{array}{l}\text { Perceived } \\
\text { benefits }\end{array}$} & $\begin{array}{l}\text { Adherence to } \\
\text { the principles } \\
\text { of prevention } \\
\text { has important } \\
\text { effect on the } \\
\text { course of } \\
\text { COVID-19 } \\
\text { disease }\end{array}$ & 49 (2.6) & $58(3.1)$ & $82(4.4)$ & $1161(62.4)$ & $\begin{array}{l}511 \\
(27.5)\end{array}$ & $\begin{array}{l}8.7 \pm \\
1.1\end{array}$ \\
\hline & $\begin{array}{l}\text { I stay home so } \\
\text { that fewer } \\
\text { people get } \\
\text { infected and } \\
\text { the epidemic of } \\
\text { the disease is } \\
\text { controlled } \\
\text { sooner }\end{array}$ & $26(1.4)$ & $13(0.7)$ & 35 (1.9) & $353(19.0)$ & $\begin{array}{l}1434 \\
(77.1)\end{array}$ & \\
\hline
\end{tabular}

The significant differences was not seen in perceived sensitivity and severity among men and females but the mean score of perceived benefits in women was significantly higher than men. The employees had significantly higher mean score in perceived sensitivity, severity and benefits. Also, the mean score of perceived sensitivity in age group of 31-40 years, perceived severity and benefits in people over 50 years was significantly higher than other age groups $(P<0.05)$. The results showed that the mean score of perceived sensitivity was higher significantly in single participants the mean score of perceived severity and benefits was significantly higher in married participants than others were $(P<0.05)$. [Table 3] 
Table 3

- Comparison of HBM constructs between gender, age groups, jobs and marital status

\begin{tabular}{|c|c|c|c|c|c|}
\hline \multirow[t]{2}{*}{ Variables } & & \multicolumn{2}{|c|}{ behavior total } & \multicolumn{2}{|c|}{ Attitude total } \\
\hline & & Mean \pm SD & & Mean & $\mathrm{P}$ \\
\hline \multirow[t]{2}{*}{ Gender } & Male & $54.16 \pm 10$ & \multirow[t]{2}{*}{$<0.001$} & $55.5 \pm 9.4$ & \multirow[t]{2}{*}{$<0.001$} \\
\hline & Female & $56.92 \pm 8.2$ & & $57.5 \pm 7.6$ & \\
\hline \multirow[t]{5}{*}{ Age group } & $10-20$ & $54.3 \pm 11.5$ & \multirow[t]{5}{*}{0.01} & $52.5 \pm 12.2$ & \multirow[t]{5}{*}{0.003} \\
\hline & $21-30$ & $56.4 \pm 8.6$ & & $55.3 \pm 9.4$ & \\
\hline & $31-40$ & $57.1 \pm 7.6$ & & $56.2 \pm 8.4$ & \\
\hline & $41-50$ & $55.9 \pm 9.5$ & & $55.2 \pm 9.9$ & \\
\hline & More than 50 & $57.4 \pm 8.6$ & & $56.8 \pm 8.2$ & \\
\hline \multirow[t]{6}{*}{ Jobs } & Student & $55.7 \pm 9$ & \multirow[t]{6}{*}{$<0.001$} & $54.7 \pm 9$ & \multirow[t]{6}{*}{$<0.001$} \\
\hline & Employee & $56.8 \pm 7.8$ & & $55.9 \pm 7.8$ & \\
\hline & Shopkeeper & $55.9 \pm 9$ & & $54.2 \pm 9$ & \\
\hline & House keeping & $57.6 \pm 7.9$ & & $56.9 \pm 7.9$ & \\
\hline & Agricultural and livestock jobs & $49.9 \pm 16.2$ & & $48.8 \pm 16.2$ & \\
\hline & Driver & $56.6 \pm 7.4$ & & $54.5 \pm 7.4$ & \\
\hline \multirow[t]{3}{*}{ Marital Status } & Single & $55.78 \pm 8.5$ & \multirow[t]{3}{*}{0.03} & $54.64 \pm 9$ & \multirow[t]{3}{*}{0.02} \\
\hline & Maried & $56.90 \pm 8.6$ & & $55.97 \pm 9.2$ & \\
\hline & Divorced/Widowed & $57.77 \pm 6.4$ & & $55.86 \pm 8.1$ & \\
\hline
\end{tabular}

Result showed that the majority of people believed that the items recommended in the media were effective in preventing COVID-19 disease. But 18\% (287 person) of participants, wearing masks outside the home, 3.7\% (70 person) wearing masks in contact with patients, 10.2\% (189 person) hand washing with disinfectants, $3 \%$ (56 person) washing hands with soap and water was considered to be very ineffective or ineffective.

Given that the belief in the effectiveness of each item was measured from the number 1 (minimum) to 7 (maximum), the number 4 can be considered as a doubt about the effectiveness that has been selected by a significant number of participants. [Table 4] 
Table 4

- Descriptive statistics of attitude toward the effectiveness of the recommendations to prevent COVID-19

\begin{tabular}{|c|c|c|c|c|c|c|c|}
\hline \multirow[t]{2}{*}{ Variables } & & \multicolumn{2}{|l|}{$\begin{array}{l}\text { Perceived } \\
\text { Sensitivity }\end{array}$} & \multicolumn{2}{|c|}{$\begin{array}{l}\text { Perceived } \\
\text { Severity }\end{array}$} & \multicolumn{2}{|c|}{$\begin{array}{l}\text { Perceived } \\
\text { Benefits }\end{array}$} \\
\hline & & $\begin{array}{l}\text { Mean } \pm \\
\text { SD }\end{array}$ & $\mathrm{P}$ & Mean & $\mathrm{P}$ & $\begin{array}{l}\text { Mean } \\
\pm \text { SD }\end{array}$ & $P$ \\
\hline \multirow[t]{2}{*}{ gender } & Male & $15.8 \pm 2.3$ & \multirow[t]{2}{*}{0.1} & $\begin{array}{l}16.4 \pm \\
2.0\end{array}$ & \multirow[t]{2}{*}{0.3} & $\begin{array}{l}8.6 \pm \\
1.2\end{array}$ & \multirow[t]{2}{*}{$\begin{array}{l}<.001 \\
0.001\end{array}$} \\
\hline & Female & $16.0 \pm 2.2$ & & $\begin{array}{l}16.5 \pm \\
2.0\end{array}$ & & $\begin{array}{l}8.9 \pm \\
0.9\end{array}$ & \\
\hline \multirow[t]{5}{*}{ Age group } & $10-20$ & $\begin{array}{l}15.62 \pm \\
2.6\end{array}$ & \multirow[t]{5}{*}{0.08} & $\begin{array}{l}15.8 \pm \\
2.6\end{array}$ & \multirow[t]{5}{*}{0.008} & $\begin{array}{l}8.2 \pm \\
1.7\end{array}$ & \multirow[t]{5}{*}{$\begin{array}{l}< \\
0.001\end{array}$} \\
\hline & $21-30$ & $\begin{array}{l}15.95 \pm \\
2.2\end{array}$ & & $\begin{array}{l}16.4 \pm \\
2.1\end{array}$ & & $\begin{array}{l}8.7 \pm \\
1.2\end{array}$ & \\
\hline & $31-40$ & $16.1 \pm 2.1$ & & $16.6 \pm 2$ & & $8.8 \pm 1$ & \\
\hline & $41-50$ & $15.7 \pm 2.4$ & & $\begin{array}{l}16.6 \pm \\
1.9\end{array}$ & & $\begin{array}{l}8.9 \pm \\
0.7\end{array}$ & \\
\hline & Over than 50 & $15.7 \pm 2.2$ & & $\begin{array}{l}16.8 \pm \\
1.7\end{array}$ & & $\begin{array}{l}8.9 \pm \\
0.9\end{array}$ & \\
\hline \multirow[t]{6}{*}{ Jobs } & Student & $\begin{array}{l}15.99 \pm \\
2.2\end{array}$ & \multirow[t]{6}{*}{0.13} & $\begin{array}{l}16.3 \pm \\
2.2\end{array}$ & \multirow[t]{6}{*}{0.18} & $\begin{array}{l}8.60 \pm \\
1.4\end{array}$ & \multirow[t]{6}{*}{0.009} \\
\hline & Employee & $16.11 \pm 2$ & & $\begin{array}{l}16.68 \pm \\
1.9\end{array}$ & & $\begin{array}{l}8.88 \pm \\
0.9\end{array}$ & \\
\hline & Shopkeeper & $\begin{array}{l}15.86 \pm \\
2.3\end{array}$ & & $\begin{array}{l}16.56 \pm \\
2\end{array}$ & & $\begin{array}{l}8.74 \pm \\
1\end{array}$ & \\
\hline & House keeping & $\begin{array}{l}15.97 \pm \\
2.3\end{array}$ & & $\begin{array}{l}16.53 \pm \\
2\end{array}$ & & $\begin{array}{l}8.84 \pm \\
1\end{array}$ & \\
\hline & $\begin{array}{l}\text { Agricultural and } \\
\text { livestock jobs }\end{array}$ & $\begin{array}{l}15.26 \pm \\
2.2\end{array}$ & & $\begin{array}{l}16.13 \pm \\
2.4\end{array}$ & & $\begin{array}{l}8.66 \pm \\
1.5\end{array}$ & \\
\hline & Driver & $\begin{array}{l}15.59 \pm \\
2.6\end{array}$ & & $\begin{array}{l}16.52 \pm \\
2.2\end{array}$ & & $\begin{array}{l}8.68 \pm \\
1.2\end{array}$ & \\
\hline \multirow[t]{3}{*}{$\begin{array}{l}\text { Marital } \\
\text { status }\end{array}$} & Single & $\begin{array}{l}16.13 \pm \\
2.1\end{array}$ & \multirow[t]{3}{*}{0.02} & $\begin{array}{l}16.41 \pm \\
2.2\end{array}$ & \multirow[t]{3}{*}{0.04} & $\begin{array}{l}8.5 \pm \\
1.4\end{array}$ & \multirow[t]{3}{*}{$\begin{array}{l}< \\
0.001\end{array}$} \\
\hline & Maried & $\begin{array}{l}15.93 \pm \\
2.2\end{array}$ & & $\begin{array}{l}16.59 \pm \\
1.9\end{array}$ & & $\begin{array}{l}8.86 \pm \\
0.9\end{array}$ & \\
\hline & Divorced/Widowed & $\begin{array}{l}15.19 \pm \\
2.9\end{array}$ & & $\begin{array}{l}15.93 \pm \\
2.4\end{array}$ & & $\begin{array}{l}8.47 \pm \\
1.3\end{array}$ & \\
\hline
\end{tabular}


Results showed that the majority of participants adhered the recommended behaviors about prevention from COVID-19 disease. But 18.1\% (337 person) reported never, rarely and very little times wearing gloves outside the home, also $21.6 \%$ (402 person) about wearing masks outside the home, 6.1\% (114 person) about wearing masks in contact with patients and suspicious people, $12.8 \%$ ( 239 person) about washing their hands with disinfectants, 3.9\% (73 person) about washing their hands with soap and water rported the same behavior adherence. Given that the adherence to the recommended behaviors for each item was measured from 1 (minimum) to 7 (maximum), the number 4 can be considered as incomplete adherence to the recommendations which is selected by a significant number of participants. [Table 5]

Table 5

- Descriptive statistics of behavior adherence toward the recommendations to prevent COVID-19

\begin{tabular}{|c|c|c|c|c|c|c|c|}
\hline \multirow[t]{2}{*}{ Item } & \multicolumn{7}{|c|}{ The rate effectiveness of recommendation } \\
\hline & 1 & 2 & 3 & 4 & 5 & 6 & 7 \\
\hline $\begin{array}{l}\text { Wearing gloves } \\
\text { outside the home }\end{array}$ & $110(5.9)$ & $65(3.5)$ & $112(6.0)$ & 209(11.2) & $272(14.6)$ & $\begin{array}{l}148 \\
(8.0)\end{array}$ & $\begin{array}{l}945 \\
(50.8)\end{array}$ \\
\hline $\begin{array}{l}\text { Wearing mask } \\
\text { outside the home }\end{array}$ & 134(7.2) & 68(3.7) & 133(7.1) & $232(12.5)$ & $267(14.3)$ & $\begin{array}{l}184 \\
(9.9)\end{array}$ & $\begin{array}{l}843 \\
(45.3)\end{array}$ \\
\hline $\begin{array}{l}\text { Wearing masks in } \\
\text { contact with patients } \\
\text { and suspicious } \\
\text { people }\end{array}$ & $51(2.7)$ & $13(0.7)$ & $6(0.3)$ & $22(1.2)$ & $35(1.9)$ & $\begin{array}{l}43 \\
(2.3)\end{array}$ & $\begin{array}{l}1690 \\
(90.8)\end{array}$ \\
\hline Stay at home & $49(2.6)$ & $2(0.1)$ & $11(0.6)$ & $25(1.3)$ & $50(2.7)$ & $\begin{array}{l}99 \\
(5.3)\end{array}$ & $\begin{array}{l}1625 \\
(87.3)\end{array}$ \\
\hline $\begin{array}{l}\text { Lack of attendance at } \\
\text { family and religious } \\
\text { ceremonies }\end{array}$ & $57(3.1)$ & $20(1.1)$ & $4(0.2)$ & $15(0.8)$ & $39(2.1)$ & $\begin{array}{l}79 \\
(4.2)\end{array}$ & $\begin{array}{l}1647 \\
(88.5)\end{array}$ \\
\hline $\begin{array}{l}\text { Minimize public } \\
\text { presence such as } \\
\text { purchases and } \\
\text { banking }\end{array}$ & $53(2.8)$ & $266(0.3)$ & $8(0.4)$ & $25(1.3)$ & $65(3.5)$ & $\begin{array}{l}153 \\
(8.2)\end{array}$ & $\begin{array}{l}1551 \\
(83.3)\end{array}$ \\
\hline $\begin{array}{l}\text { Hand washing after } \\
\text { contact with outdoor } \\
\text { equipment with } \\
\text { disinfectant }\end{array}$ & $80(4.3)$ & $29(1.6)$ & $80(4.3)$ & 154(8.3) & 205(11.0) & $\begin{array}{l}151 \\
(8.1)\end{array}$ & $\begin{array}{l}1162 \\
(62.4)\end{array}$ \\
\hline $\begin{array}{l}\text { Wash hands after } \\
\text { contact with outdoor } \\
\text { appliances with soap } \\
\text { and water }\end{array}$ & $48(2.6)$ & $4(0.2)$ & $4(0.2)$ & $21(1.1)$ & $47(2.5)$ & $\begin{array}{l}100 \\
(5.4)\end{array}$ & $\begin{array}{l}1637 \\
\text { (88) }\end{array}$ \\
\hline $\begin{array}{l}\text { Disinfect personal } \\
\text { items such as keys, } \\
\text { mobile phones and } \\
\text { cars }\end{array}$ & $56(3.0)$ & $4(0.2)$ & $18(1.0)$ & $34(1.8)$ & $80(4.3)$ & $\begin{array}{l}145 \\
(7.8)\end{array}$ & $\begin{array}{l}1524 \\
(81.9)\end{array}$ \\
\hline
\end{tabular}


Analysis of the results in Table 5 showed that total attitude score and staying at home can behavior in a significant way. According to this result, $54.7 \%$ of the total variance about behavior can be explained though this two variables. [Table 6] 
Table 6

multiple linear regression analysis about predictor of COVID-19 preventive behaviors

\begin{tabular}{|c|c|c|c|c|c|c|c|}
\hline \multirow[t]{2}{*}{ Behaviors } & \multicolumn{7}{|c|}{ Adherence rate to preventive behaviors } \\
\hline & 1 & 2 & 3 & 4 & 5 & 6 & 7 \\
\hline $\begin{array}{l}\text { Wearing gloves } \\
\text { outside the } \\
\text { home }\end{array}$ & 169(9.1) & $82(4.4)$ & $86(4.6)$ & 158(8.5) & 235(12.6) & $\begin{array}{l}192 \\
(10.3)\end{array}$ & $\begin{array}{l}939 \\
(50.5)\end{array}$ \\
\hline $\begin{array}{l}\text { Wearing mask } \\
\text { outside the } \\
\text { home }\end{array}$ & 188(10.1) & $90(4.8)$ & $124(6.7)$ & 177(9.5) & 208(11.2) & $\begin{array}{l}182 \\
(9.8)\end{array}$ & $\begin{array}{l}892 \\
(47.9)\end{array}$ \\
\hline $\begin{array}{l}\text { Wearing masks } \\
\text { in contact with } \\
\text { patients and } \\
\text { suspicious } \\
\text { people }\end{array}$ & $99(5.3)$ & $5(0.3)$ & $10(0.5)$ & $22(1.2)$ & $33(1.8)$ & $\begin{array}{l}53 \\
(2.8)\end{array}$ & $\begin{array}{l}1639 \\
(88.1)\end{array}$ \\
\hline Stay at home & $30(1.6)$ & $43(2.3)$ & $17(0.9)$ & $49(2.6)$ & $140(7.5)$ & $\begin{array}{l}192 \\
(10.3)\end{array}$ & $\begin{array}{l}1390 \\
(74.7)\end{array}$ \\
\hline $\begin{array}{l}\text { Lack of } \\
\text { attendance at } \\
\text { family and } \\
\text { religious } \\
\text { ceremonies }\end{array}$ & $66(3.5)$ & $5(0.3)$ & $15(0.8)$ & $29(1.6)$ & $48(2.6)$ & $\begin{array}{l}136 \\
(7.3)\end{array}$ & $\begin{array}{l}1557 \\
(83.7)\end{array}$ \\
\hline $\begin{array}{l}\text { Minimize public } \\
\text { presence such } \\
\text { as purchases } \\
\text { and banking }\end{array}$ & $27(1.5)$ & $26(1.4)$ & $17(0.9)$ & $48(2.6)$ & 107(5.7) & $\begin{array}{l}210 \\
(11.3)\end{array}$ & $\begin{array}{l}1426 \\
(76.6)\end{array}$ \\
\hline $\begin{array}{l}\text { Hand washing } \\
\text { after contact } \\
\text { with outdoor } \\
\text { equipment with } \\
\text { disinfectant }\end{array}$ & $108(5.8)$ & $62(3.3)$ & $69(3.7)$ & $117(6.3)$ & 211(11.3) & $\begin{array}{l}189 \\
(10.2)\end{array}$ & $\begin{array}{l}1105 \\
(59.4)\end{array}$ \\
\hline $\begin{array}{l}\text { Wash hands } \\
\text { after contact } \\
\text { with outdoor } \\
\text { appliances with } \\
\text { soap and water }\end{array}$ & $46(2.5)$ & $6(0.3)$ & $21(1.1)$ & $20(1.1)$ & $69(3.7)$ & $\begin{array}{l}130 \\
(7.0)\end{array}$ & $\begin{array}{l}1569 \\
(84.3)\end{array}$ \\
\hline \multirow{2}{*}{$\begin{array}{l}\text { Disinfect } \\
\text { personal items } \\
\text { such as keys, } \\
\text { mobile phones } \\
\text { and cars }\end{array}$} & $39(2.1)$ & $31(1.7)$ & $31(1.7)$ & $57(3.1)$ & $101(5.4)$ & $\begin{array}{l}152 \\
(8.2)\end{array}$ & $\begin{array}{l}1450 \\
(77.9)\end{array}$ \\
\hline & B & $\begin{array}{l}\text { Std. } \\
\text { Error }\end{array}$ & $\begin{array}{l}\text { Standardized } \\
\text { Beta }\end{array}$ & t & Sig. & $\mathbf{R}$ & $\begin{array}{l}\mathrm{R} \\
\text { Square }\end{array}$ \\
\hline $\begin{array}{l}\text { Total attitude } \\
\text { score }\end{array}$ & 0.748 & 0.018 & 0.696 & 41.599 & $<0.001$ & 0.74 & 0.547 \\
\hline
\end{tabular}




\begin{tabular}{|llllllll|}
\hline Behaviors & \multicolumn{7}{l|}{ Adherence rate to preventive behaviors } \\
\cline { 2 - 7 } & $\mathbf{1}$ & $\mathbf{2}$ & $\mathbf{3}$ & $\mathbf{4}$ & $\mathbf{5}$ & $\mathbf{6}$ & $\mathbf{7}$ \\
\hline Stay at home & 1.414 & 0.228 & 0.104 & 6.212 & $<0.001$ & & \\
\hline
\end{tabular}

\section{Discussion}

This study aimed to explain an Iranian population's risk perception and adherence to preventive health recommendations regarding the COVID-19 infection. Based on the structural constructs of the health belief model, the perceived sensitivity, severity and benefits had desirable levels in the studied population. Despite this, some people refused to have proper health behaviors required to prevent and control the disease. Moreover, this study showed that the "attitude towards the disease" and "the intention to stay at home" were the most important predictors of health behaviors in the community.

Our findings showed that women had better behavior and attitude than men regarding the prevention of COVID-19. This was despite the fact that men generally experience a more severe form of the disease and have a higher risk of mortality (22). In this study, attitude, and perceived benefits were better in women than in men. In contrast, the findings of Abdul-Hafez et al. showed that men and women had the same levels of knowledge and attitude regarding the COVID-19 disease (23). Likewise, another study on the $\mathrm{H} 1 \mathrm{~N} 1$ pandemic revealed a better preventive function in women compared with men (24). These discrepancies between genders can be related to the personality differences of men and women as females are generally much more sensitive and influential than males in perceiving their surroundings. Therefore, it is necessary to use appropriate sensitization methods to help men to better understand the benefits of adhering to the COVID-19 preventive measures.

In this study, the knowledge and behavior about the disease were different in various age groups. People over the age of 50 years had better perceptions and behaviors facing the disease. One of the reasons of this can be a misunderstanding that has spread on social media as only older people are at risk of this disease (25). Contrary to the findings of this study, other reports have shown that younger people possess better knowledge and attitudes towards the disease and its preventive measures (23). This may be related to social, cultural, political, and economic differences among different communities. According to the findings of Abdul Hafez et al., older age, lower literacy and income, as well as living in rural areas were associated with inferior knowledge about the disease (23).

In this study, housewives had good perception and behaviors. On the other hand, farmers and drivers had low knowledge and bad behaviors towards the disease. This observation of ours was similar to that of another study noting better knowledge and attitude about the disease and its preventive measures in people living in city compared with those living in rural areas or people with an income less than 5000 pounds per month (23). It seems that access to social media, having free time to search into information resources, educational level, and social culture can be determining factors regarding the knowledge and behavior about the COVID-19 infection. Usually, people living in rural areas have limited access to 
scientific facilities, poor studying habits, as well as lower income and shorter free time than residents of urban regions have. So, it is required to improve awareness and attitude about the disease by implementing appropriate programs, especially across low-income communities.

Our study's findings showed that sensitization toward the disease was well established in our participants who had seen themselves at the risk of the infection. In fact, there was a fear of the disease among the population. The perceived sensitivity was higher in middle-aged people (30 to 40 years) than others. This may reflect a sense of curiosity, activism, and better access to social media and the Internet in this age group. Becoming alert to the threats and consequences of the disease can augment the rate of adherence to preventive health behaviors. Furthermore, we noticed that the perceived severity was higher in individuals over 50 years than those in other age groups. This may be explained by the fact that the elderly and people with underlying diseases can experience a more severe form of the disease, which ultimately leads to a higher mortality rate in these groups. Actually, our participants were fully aware of this fact, which was in parallel to the findings of another study indicating the perceived severity as an important predictor of adherence to health behaviors(26). Yet another study showed that perceived severity was positively associated with negative emotions and higher utilization of mobile phones leading to more appropriate health behaviors to confine the COVID-19 infection (27).

Our findings showed that the perceived sensitivity was higher in single people. On the other side, the perceived severity and benefits were higher in married individuals. This can be attributed to the more free time and better access to data resources of single people and to the fact that married individuals are more attached to their martial life. On the same premise, married individual can have a higher perception towards environmental threats. We also found that the perceived benefits were greater in the elderly than young individuals. As explanation, one can say that a higher perceived severity and the fear of the disease complications would lead the elderly to better understood the advantages of preventive behaviors (i.e. regular hand-washing, applying facemasks, and keeping social distancing).

The findings of the present study indicated homogeneous perceived sensitivity and severity comparing women and men; nevertheless, perceived benefits were better in women than in men. This was in parallel with another study suggesting that parameters such as moving to a new neighborhood, having good knowledge and awareness about the disease, and the fear of the disease can encourage observing health behaviors (28).

In this study, the majority of the participants noted that they obtained the required information about the disease and preventive measures through social media. Still, some of them had low adherence to health behaviors. In line with the findings of this study, it has been reported that most people acquire their knowledge about the disease through social media and the Internet (23). In the another study, despite the good knowledge of general population about the transmission patterns and common symptoms of COVID-19 disease, they misunderstood preventive actions because of confusing information circulating on social media (29). As people may perpetrate incorrect behaviors such as unauthorized consumption of antibiotics (25), it is important to improve people's knowledge and awareness about the disease and 
preventive actions through formal and valid websites and mass media, as well as educations by knowledgeable and trusted individuals such as doctors, nurses and other health staff.

The results of our study showed that most the participants abided by the disease prevention behaviors. People's beliefs about the effectiveness of treatments can be among factors influencing the rate of behavioral compliance (30). Therefore, providing accurate and reliable information along with necessary personal protective equipment (PPEs) can increase the rate of public adherence to health behaviors amid this pandemic (31). Although a large portion of our participants followed health behaviors, but there were also people who, despite good perceived sensitivity and severity and high awareness, ignored these behavioral protocols. One of the most important reasons for this phenomenon may be people getting used to the situation through the time. Other influencing factors include economic problems and either a shortage in or high-price of PPEs (32).

In this study, it was shown that two variables; attitude towards the disease and tendency to stay at home, predicted more than $50 \%$ of the variance of COVID-19 preventive social health behaviors. This was in line with the findings of two studies in China showing the efficiency of lock-down to significantly reduce the incidence and mortality of COVID-19 infection $(33,34)$. According to the guidelines of the WHO, one important way to control and manage the disease is to keep social distancing and avoid attending group meetings (35). The public staying at home requires a national, social and personal determination. In order to encourage people to stay at home, the infrastructure must first be provided, and schools and universities should be closed and continue education through on-line courses. The recent activity itself requires appropriate infrastructure and the preparation of teachers and students. Furthermore, organizations and agencies that provide essential services should continue to operate with minimal staff. The livelihood needs of the public should be provided, and broadcasting agencies should display entertainment programs. On the other hand, some people who may not have a regular income (i.e. day workers) must be supported by governments and non-governmental organization (NGO). In this way, it is necessary to pave the road for the public to keep social distancing and adhere to required health behaviors.

\section{Limitations}

One of the limitations of this study was that it was performed electronically into the context of social media to keep the researchers and participants safe. Therefore, the controlling of cofounding variables and inclusion/exclusion criteria may has been somehow limited. By considering a relatively large sample size, we tried to overcome this limitation to some extent. Another limitation of this study was the unavoidable exclusion of deprived social groups who did not own smartphones or access to social media. This should be considered when generalizing our data to other communities.

\section{Conclusion}


Based on the structural constructs of the health belief model, we showed optimal levels of perceived sensitivity, severity and benefits among our participants. Despite this; some people still did not comply with appropriate preventive health behaviors to confine the COVID-19 infection. The most important factors predicting social healthy behaviors were the attitude towards the disease and the intention to stay at home. Complying with healthy behaviors was lower in middle-aged and younger people than the elderly, which may root in a myth stating that only older people are affected by the disease. So, it is suggested to provide the public with reliable, accurate, and scientific information sources by creating valid databases. Our study showed that although the majority of the study participants followed the disease prevention behaviors, there were also individuals who did not adhere to these health behaviors. Therefore, it is necessary to identify and resolve barriers leading these people to not to comply with health behaviors. Two variables; the attitude towards the disease and the intention to stay at home, predicted more than $50 \%$ of the variance observed in the adherence to preventive health behaviors across the community. Finally, providing the necessary infrastructure can encourage people to stay at home and comply with social distancing protocols amid the pandemic.

\section{Abbreviations}

ARUMS

Ardabil University of Medical Sciences

HBM

Health Belief Model

NGO

Non-Governmental Organization

PPEs

Personal Protective Equipment

CVI

Content Validity Index

CVR

Content Validity Ratio

\section{Declarations}

\section{Ethics approval and consent to participate}

This study was examined by the ethics committee of the Ardabil University of Medical Sciences and received approval with the ethics code of IR.ARUMS.REC.1399.033. We explained the objectives of the study sufficiently in first section of the electronic instrument, participating to study was voluntarily and participation and it was based solely on the participants' full consent. In order to obtain the parental consent, in the demographic section of the questionnaire, it was mentioned that the completion of the questionnaire is possible for the age group under 20 years of age (first age group in the current study) only with the consent of the parents and must be completed under their supervision. Details of the 
sampling method and data gathering have been approved by the University's Ethical Committee and the Social Determinants Health Research Center.

\section{Consent for publication}

Not applicable.

\section{Availability of data and materials}

The original data are available on request to the corresponding author, after the manuscript published. Whatever, we also considered to provide the original data in public repositories.

\section{Competing interests}

The authors declare that they have no competing interests.

\section{Funding}

This study was supported by research deputy of ARUMS. The role of funding body included assessing the methodology the study and writing the manuscript.

\section{Authors' Contributions}

$\mathrm{HH}$ is the correspondence author of this study, responsible for designing, organizing and planning this study. AP, Khl and RND provided feedback, review the manuscript to aid in revisions. AK is responsible for data collection and analyzing, designing and planning this study. All authors have read and approved the manuscript

\section{Acknowledgements}

The authors would like to thank the Nima Masoumi who design electronic instrument for this study.

\section{References}

1. Guo YR, Cao QD, Hong ZS, Tan YY, Chen SD, Jin HJ, et al. The origin, transmission and clinical therapies on coronavirus disease 2019 (COVID-19) outbreak - an update on the status. Mil Med Res. 2020;7(1):11.

2. Dureab F, Al-Awlaqi S, Jahn A. COVID-19 in Yemen: preparedness measures in a fragile state. Lancet Public Health. 2020.

3. Fu L, Wang B, Yuan T, Chen X, Ao Y, Fitzpatrick T, et al. Clinical characteristics of coronavirus disease 2019 (COVID-19) in China: A systematic review and meta-analysis. J Infect. 2020.

4. Hui DS, I Azhar E, Madani TA, Ntoumi F, Kock R, Dar O, et al. The continuing 2019-nCoV epidemic threat of novel coronaviruses to global health-The latest 2019 novel coronavirus outbreak in Wuhan, China. International Journal of Infectious Diseases. 2020;91:264-6. 
5. Hargreaves J, Davey C. Three lessons for the COVID-19 response from pandemic HIV. The lancet HIV. 2020;7(5):e309-e11.

6. Arab-Mazar Z, Sah R, Rabaan AA, Dhama K, Rodriguez-Morales AJ. Mapping the incidence of the COVID-19 hotspot in Iran - Implications for Travellers. Travel Med Infect Dis. 2020:101630.

7. Cava MA, Fay KE, Beanlands HJ, McCay EA, Wignall R. Risk perception and compliance with quarantine during the SARS outbreak. J Nurs Scholarsh. 2005;37(4):343-7.

8. Bodas M, Peleg K. Self-Isolation Compliance In The COVID-19 Era Influenced By Compensation: Findings From A Recent Survey In Israel. Health Aff (Millwood). 2020:101377hlthaff202000382.

9. Paakkari L, Okan O. COVID-19: health literacy is an underestimated problem. Lancet Public Health. 2020;5(5):e249-e50.

10. Harper CA, Satchell LP, Fido D, Latzman RD. Functional Fear Predicts Public Health Compliance in the COVID-19 Pandemic. Int J Ment Health Addict. 2020:1-14.

11. Holmes EA, O'Connor RC, Perry VH, Tracey I, Wessely S, Arseneault L, et al. Multidisciplinary research priorities for the COVID-19 pandemic: a call for action for mental health science. Lancet Psychiatry. 2020.

12. Houghton C, Meskell P, Delaney H, Smalle M, Glenton C, Booth A, et al. Barriers and facilitators to healthcare workers' adherence with infection prevention and control (IPC) guidelines for respiratory infectious diseases: a rapid qualitative evidence synthesis. Cochrane Database Syst Rev. 2020;4:Cd013582.

13. Yezli S, Khan A. COVID-19 social distancing in the Kingdom of Saudi Arabia: Bold measures in the face of political, economic, social and religious challenges. Travel Med Infect Dis. 2020:101692.

14. Webster RK, Brooks SK, Smith LE, Woodland L, Wessely S, Rubin GJ. How to improve adherence with quarantine: rapid review of the evidence. Public Health. 2020;182:163-9.

15. Rosenstock IM. Why people use health services. Milbank Mem Fund Q. 1966;44(3):Suppl:94-127.

16. Hochbaum GM. Public participation in medical screening programs: A socio-psychological study: US Department of Health, Education, and Welfare, Public Health Service ...; 1958.

17. Akter J. Title: Human Behavior toward COVID-19. 2020.

18. Carico RR, Jr., Sheppard J, Thomas CB. Community pharmacists and communication in the time of COVID-19: Applying the health belief model. Res Social Adm Pharm. 2020.

19. Mukhtar S. Mental health and emotional impact of COVID-19: Applying Health Belief Model for medical staff to general public of Pakistan. Brain, Behavior, and Immunity. 2020.

20. Azadbakht M, Garmaroodi G, Taheri Tanjani P, Sahaf R, Shojaeizade D, Gheisvandi E. Health promoting self-care behaviors and its related factors in elderly: application of health belief model. $\mathrm{J}$ Educ Community Health. 2014;1(2):20-9.

21. Amirzadeh Iranagh J, Motallebi S. The effect of health belief model based on education intervention on physical activity of elderly women. The Journal of Urmia Nursing and Midwifery Faculty. 2016;13(12):1050-8. 
22. Jin J-M, Bai P, He W, Wu F, Liu X-F, Han D-M, et al. Gender differences in patients with COVID-19: Focus on severity and mortality. Frontiers in Public Health. 2020;8:152.

23. Abdelhafiz AS, Mohammed Z, Ibrahim ME, Ziady HH, Alorabi M, Ayyad M, et al. Knowledge, Perceptions, and Attitude of Egyptians Towards the Novel Coronavirus Disease (COVID-19). Journal of Community Health. 2020.

24. Lau JT, Griffiths S, Choi KC, Tsui HY. Avoidance behaviors and negative psychological responses in the general population in the initial stage of the H1N1 pandemic in Hong Kong. BMC Infectious Diseases. 2010;10(1):139.

25. Geldsetzer P. Using rapid online surveys to assess perceptions during infectious disease outbreaks: a cross-sectional survey on Covid-19 among the general public in the United States and United Kingdom. medRxiv. 2020:2020.03.13.20035568.

26. Powe BD. Cancer fatalism among elderly African American women: predictors of the intensity of the perceptions. Journal of Psychosocial Oncology. 2001;19(3-4):85-95.

27. Li J-B, Yang A, Dou K, Wang L-X, Zhang M-C, Lin X. Chinese public's knowledge, perceived severity, and perceived controllability of the COVID-19 and their associations with emotional and behavioural reactions, social participation, and precautionary behaviour: A national survey. 2020.

28. Kwok KO, Li KK, Chan HH, Yi YY, Tang A, Wei WI, et al. Community responses during the early phase of the COVID-19 epidemic in Hong Kong: risk perception, information exposure and preventive measures. medRxiv. 2020:2020.02.26.20028217.

29. Geldsetzer P. Knowledge and Perceptions of COVID-19 Among the General Public in the United States and the United Kingdom: A Cross-sectional Online Survey. Annals of Internal Medicine. 2020.

30. Diefenbach MA, Leventhal $H$. The common-sense model of illness representation: Theoretical and practical considerations. Journal of social distress and the homeless. 1996;5(1):11-38.

31. Who. Covide-19 strategy update. Available from: https://www.who.int/publications-detail/covid-19strategy-update--14-april-2020. Accessed: May 3, 2020.

32. Organization WH. Rational use of personal protective equipment for coronavirus disease ( COVID19) and considerations during severe shortages: interim guidance, 6 April 2020. World Health Organization; 2020.

33. de Figueiredo AM, Codina AD, Moreira DC, Figueiredo M, Saez M, León AC. Impact of lockdown on COVID-19 incidence and mortality in China: an interrupted time series study.

34. Lau H, Khosrawipour V, Kocbach P, Mikolajczyk A, Schubert J, Bania J, et al. The positive impact of lockdown in Wuhan on containing the COVID-19 outbreak in China. Journal of Travel Medicine. 2020.

35. Who. Coronavirus disease (COVID-19) advice for the public. Available from: https://www.who.int/emergencies/diseases/novel-coronavirus-2019/advice-for-public. Accessed: May 3, 2020.

\section{Supplementary Files}


This is a list of supplementary files associated with this preprint. Click to download.

- Additionalfile.docx 